\title{
KAPASZKODJUNK FELJEBB A GLOBÁLIS EGYETEMI RANGSOROKBAN!
}

\section{MOVING AHEAD IN THE GLOBAL UNIVERSITY RANKINGS}

\author{
Bőgel György ${ }^{*}$, Mátyás László ${ }^{* *}$ \\ *a közgazdaság-tudomány kandidátusa, Közép-európai Egyetem, Budapest \\ bogelgy@ceu.edu \\ *az MTA doktora, Közép-európai Egyetem, Budapest \\ Matyas@ceu.edu
}

\begin{abstract}
ÖSSZEFOGLALÁS
Hazai egyetemeink gyengén szerepelnek a globális felsőoktatási intézményi rangsorokban. Ezen a helyzeten változtatni kell és lehet. A cikk rávilágít arra, hogy miért kellene egyes magyar egyetemeknek, illetve egyetemi részlegeknek bekerülniük a nemzetközi tudományegyetemi élvonalba. Rövid áttekintést ad a hazai felsőoktatás állapotáról, majd fokozatosan kiterjeszthető reformkísérletre tesz javaslatot. Bemutatja azokat a működési elveket, amelyektől eredményeket várhatunk, valamint hozzávetőleges számítások alapján javaslatot tesz a kiterjesztés mértékére, végezetül röviden szól a kockázatokról is. ${ }^{1}$
\end{abstract}

\begin{abstract}
Hungarian universities are lagging behind in the global university rankings. Overcoming this weakness is necessary and feasible. In this paper, we highlight why the country needs this improvement and why some Hungarian universities or university units must move to the group of top tier institutions of higher education. A short overview is provided on the present status of the country's higher education and a plan is presented for an experimental reform to be extended gradually. The operating principles recommended are listed and explained, a draft calculation is presented for assessing scalability, and finally some key risk factors are discussed.
\end{abstract}

Kulcsszavak: egyetemi rangsorok, felsőoktatási reform, tudományegyetem, egyetemi stratégia, tudománypolitika, oktatáspolitika

Keywords: university rankings, higher education reform, research university, university strategy, science policy, education policy

${ }^{1}$ A szerzők, akik a témáról korábban két írást tettek közzé az Index vélemény rovatában, észrevételeikért és javaslataikért köszönetet mondanak a következőknek: Berlinger Edina (BCE), Chikán Attila (BCE), Horváth Áron (ELTE), Király Júlia (IBS), Kovács Erzsébet (BCE), Körösi Gábor (MTA KRTK KTI), Lafferthon Judit (KEE), Lannert Judit (T-TUDOK), Mihályi Péter (BCE), Semjén András (MTA KRTK KTI), Temesi József (BCE), Tímár Eszter (KEE), Polónyi István (Debreceni Egyetem), Váradi Balázs (ELTE). A jelen írást is vitacikknek szánjuk, minden észrevételnek, kiegészítésnek, javaslatnak örülünk. 
Az Academic Ranking of World Universities (ARWU) 2018-as rangsorában (URL1) tizenhat amerikai egyetem található az első húsz között. A fennmaradó négyből három angol, a világ többi országát pedig egyetlen svájci egyetem képviseli. A rangsorban az első ötszáz között nincs magyar intézmény ${ }^{2}$, a második ötszázban öt hazai egyetemet találunk. Az első ötszázas körbe két lengyel (a varsói és a krakkói Jagelló) és egy cseh (a prágai Károly) egyetemnek sikerült bekerülnie, helyezésük tehát jóval kedvezőbb, mint a második csoportban szereplő magyaroké.

Az eredetileg a kínai Csiao Tung Egyetem (Jiao Tong University) által összeállított ARWU volt az első globális lista. Ma már több ,versenytársa” van, közülük talán a Times Higher Education (THE) (URL2) és a Quacquarelli Symonds (QS) ${ }^{3}$ a legtekintélyesebbek. A THE 2019-es átfogó listáján a Semmelweis jelenik meg a 400-500-as csoportban, a QS-listán a Szegedi Egyetem található meg hasonló helyezéssel.

\section{A GLOBÁLIS RANGSOROK JELENTŐSÉGE}

Felmerül a kérdés, hogy kell-e, illetve lehet-e tenni valamit a kedvezőbb helyezés érdekében. A globális, teljes intézményekre vonatkozó rangsorok hitelességét, fontosságát, a listák összeállításának módszertanát sokan vitatják, sőt olyan véleménnyel is találkozunk, hogy több kárt okoznak, mint amennyi hasznot hajtanak. ${ }^{4} \mathrm{Az}$ intézményi listákon kívül szükebb szakterületi és regionális rangsorok is napvilágot látnak, ezek népszerüsége növekszik, és tudjuk, hogy Magyarország néhányban jobb helyezést ér el, mint az intézményi rangsorokban.

A rangsorok összeállításakor számos tényezőt vesznek figyelembe. A legfontosabbnak tartott kutatási teljesítmény értékelésénél például azt veszik számításba, hogy az egyetem munkatársai milyen mennyiségü és minőségü publikációval rendelkeznek, hányan és honnan hivatkoznak rájuk, a kutatók mennyi és milyen értékü kutatási pályázatot és támogatást nyertek el, az egyetemen hány $\mathrm{PhD}$-hallgató tanul és kutat. Az oktatás minőségét és jellegét olyan mutatókkal mérik, mint a tanár-diák arány, a hazai és külföldi diákok száma, a diákok elégedettségi mutatói, a végzettek átlagos álláskeresési ideje, a fizetésük közvetlenül a tanulmányok lezárása után, illetve néhány évvel később. Az egyetemek hírnevét, elismertségét az érdekeltek (diákok, munkaadók és mások) körében végzett felmérések eredményeivel érzékeltetik.

${ }^{2}$ Az ELTE és Szeged korábban benne volt az első 500-ban, visszaesésük okainak feltárása alapos elemzést igényel.

${ }^{3} \mathrm{https}: / /$ www.qs.com/

${ }^{4}$ A globális rangsorokról, illetve problémáikról lásd például Fábri, 2016; Hazelkorn, 2015; Stack, 2016. 
Ha megvizsgáljuk a három említett globális intézményi listát, látható, hogy a kutatási teljesítmény a legfontosabb értékelési szempont. A rangsorok tehát a nagy méretü és gazdag tudományegyetemeknek kedveznek. Ebben a kategóriában Amerika szolgáltatja a mintát.

A kutatás, a tudományos munka azonban csak az egyetemek egyik funkciója. A globális rangsorokat sokan azért bírálják, mert nem szánnak kellő figyelmet az egyetem másik alapfeladatára, az oktatásra, egyrészt, mert kevésbé tartják fontosnak, másrészt, mert az oktatás eredményességét nehezebb mérni és számszerüsíteni. Az oktatás területén globális trendnek tekinthető az egyetemi tömegoktatás megjelenése és elterjedése.

Elit tudományegyetem az egyik oldalon, tömegoktatásra berendezkedett iskolák a másikon - vajon melyik a követendő modell, mi a helyes arány, melyik hasznosabb a társadalomnak, melyikbe érdemes befektetni? Ez a felsőoktatás fejlesztésének egyik alapvető dilemmája. Tegyük fel ismét a kérdést: Magyarországnak érdemes-e törődnie a tudományos teljesítményt hangsúlyozó globális intézményi rangsorokban elért pozíciójával, érdemes-e, kell-e tenni valamit helyezésünk javításáért, vagy elégedjünk meg azzal, hogy intézményi szinten ott vagyunk a „második ötszázban”, néhány szakterületi listán pedig valóban jól szerepelünk?

Bár a listák egyáltalán nem tökéletesek, nagy hiba lenne figyelmen kívül hagyni azokat. A rangsorok léteznek és hatnak: befolyásolják a tehetséges hallgatók és a felkészült oktatók mozgását, a pénz áramlását, és óriási nyilvánosságot élveznek. Az általános alacsony helyezés azt üzeni a világnak, hogy az ország gazdasága gyengélkedik, innovációs képessége csekély, vezetői nem törődnek megfelelően a tudományos élettel, nem becsülik a tudományos munkát, felkészült és kreatív szakembereket máshonnan kell hozni. A kutatási pályázatok döntéshozói számára a pályázók előkelő helyezése garanciát jelent a források hasznosulására.

A mai oktatási és munkaerőpiac nem helyi, nem „magyar”, hanem nemzetközi, sőt globális. Ha nem vagyunk elég erősek a felsőoktatás területén, elveszíthetjük a legtehetségesebb hallgatókat és kutatókat, amivel súlyos kárt okozunk a gazdaságnak és a társadalomnak. Egy jól működő felsőoktatási szektor jelentős hatással van az ország gazdasági fejlődésére, az ott élők életszínvonalára, tehát valódi húzóágazat lehet.

\section{VERSENY A JOBB HELYEZÉSÉRT}

Felsőoktatási rendszerünk versenyképességének fokozása tehát nem tür halasztást. Meg kell próbálnunk feljebb kapaszkodni a rangsorokon!

A versenymezőny változik. Állapotuktól, anyagi helyzetüktől és gondolkodásmódjuktól függően a különböző országok eltérő fejlesztési megoldásokkal kísérleteznek. Németország 2005-ben indította el „Exzellenzinitiative” program- 
ját, Franciaországban Nicolas Sarkozy, az akkori elnök pedig 2011-ben jelentette be, hogy programot indít egy „Sorbonne Liga” nevü, fél tucat intézményből álló, a több tízezer kutatót foglalkoztató francia Nemzeti Tudományos Kutatási Központtal összekapcsolt egyetemi klaszter megteremtésére. Az Oroszországban elindított ,5-100” elnevezésű projekt pedig azt célozta meg, hogy öt helyi intézményt juttasson be a cikk elején említett THE-rangsor százas élmezőnyébe. Ausztrália vagy Spanyolország sikere jelzi, hogy a kitörés nem lehetetlen, a felsőoktatás rangja és teljesítménye számottevően emelhetö.

Miért nem szerepelnek jól hazai egyetemeink a globális rangsorokon? A teljesség igénye nélkül néhány általánosnak tekinthető problémát sorolunk fel, miközben elismerjük, hogy biztató, bár sajnos elszigetelt kivételek is akadnak, hiszen vannak például valóban nemzetközi hírü kutatóink, akik a legjobb tudományos folyóiratokban is publikálnak. ${ }^{5}$

Egyetemeink nemzetközi mércével mért kutatási teljesítménye meglehetősen gyenge. A PhD-képzés sok helyen alacsony színvonalú, és teljesen szétforgácsolódott, ezért alapos felülvizsgálatra szorul. A legtöbb hazai intézményben túlságosan alacsony a tanár-diák arány, vagyis a tanárok idejét az oktatás köti le. Azoknak a fiataloknak, akiknek éppen a kutatói pályán kellene bizonyítaniuk, nagyon magas óraszámban kell oktatniuk.

A tanári karban kevés külföldi akad, és arra is kevés a példa, hogy külföldön tanult, sikeres kutatók hazatérnek. Elterjedt gyakorlat a belterjesség: az egyetem saját végzett PhD-hallgatóit veszi fel oktatónak, ami gátolja az új gondolatok rendszeres beáramlását. Néhány tiszteletre méltó kivételtől eltekintve (például az orvos-, a fogorvos- és az állatorvosképzés) az idegen (többnyire angol vagy német) nyelvű programok száma kicsi, kevés külföldi diák tanul nálunk, vagyis a hazai hallgatóknak a szükségesnél jóval kevesebb lehetőségük nyílik arra, hogy felkészült, tehetséges, más kultúrákból érkező tanulókkal dolgozzanak és versenyezzenek.

Tévedés lenne a fenti problémákért kizárólag az egyetemeinket hibáztatni. Az állam 2012-től kezdődően jelentős forráselvonást hajtott végre a felsőoktatásban, amit egyetemeink csak részben tudtak saját bevételeikkel ellensúlyozni, a kiadásokat ezért jelentősen vissza kellett fogni, és müködési zavarok is keletkeztek. Az egyetemi autonómiát korlátozták, a kancellárok megjelenésével az intézményeknél „kettős hatalom” alakult ki a maga furcsaságaival. Az egyetemi oktatói-kutatói pálya anyagilag nem vonzó, a fizetések nem versenyképesek. Gyakori, hogy egy intézménynek saját munkatársai magánvállalkozásaival kell versenyeznie oktatási vagy kutatási megbízásokért.

\footnotetext{
${ }^{5}$ A hazai felsőoktatás állapotáról, a reformkísérletekről lásd például Berács et al., 2015; Polónyi-Tímár, 2001; Mihályi, 2018.
} 
Az oktatás sok hazai intézményben nem hallgatóközpontú, vagyis elsősorban nem a hallgatók fejlesztését szolgálja, hanem csupán a tananyag „leadását” célozza. Az oktatás digitalizálása néhány kivételtől eltekintve lassan halad. Az interdiszciplináris kezdeményezések kari és tanszéki érdekellentétek miatt sokszor eleve halálra vannak ítélve.

Az érettségizők száma hosszú ideje csökken. A tehetséges középiskolások közül sokan külföldön tanulnak tovább, a felvételi merítés szükül, az egyetemekre sok felkészületlen és motiválatlan hallgató kerül be. A közoktatás súlyos problémái miatt sok tehetséges fiatal vész el a felsőoktatás számára.

Mindezek mellett azt a történelmi örökséget is kezelnünk kell, hogy a hazai felsőoktatás intézményrendszere túlságosan széttagolt, túl sok intézmény dolgozik párhuzamosan. Az ARWU 500-ban szereplö lengyel és cseh intézmények más méretnagyságot és komplexitást képviselnek.

\section{KÍSÉRLETEZÉS ÉS KITERJESZTÉS}

A felsőoktatás összetett, sokelemü rendszer, amelynek intézményei többféle módon szakosodhatnak, következésképpen eltérő versenypályákon és módokon lehetnek kiválóak. A legfejlettebb országok felsőoktatási rendszere is tarka, az élvonalbeli tudományegyetemek mellett sokféle más iskola is megjelenik bennük, és még a legjobb egyetemeken sem egyformán erős minden kar és tanszék.

A fejlesztési stratégiának szelektívnek kell lennie: az „oktatási piramis” csúcsán helyet kell adni a nemzetközi élmezőnyt képviselő tudományegyetemeknek, illetve egyes kiemelkedő teljesítményt nyújtó karoknak, tanszékeknek. Létük rendkívül előnyös a teljes rendszer számára, hiszen példát mutatnak, emelik a versengés színvonalát, élen járnak a tananyagok megújításában. Az ország megítélése szempontjából csak a komoly kutatást folytató tudományegyetemek számítanak.

Hogyan juthatnának feljebb egyes egyetemeink a globális rangsorokon?

Jamil Salmi, a Világbank felsőoktatási kérdésekkel foglalkozó munkatársa 2009-ben Hogyan épitsünk világszínvonalú egyetemeket? címen publikálta tanulmányát. Ebben megállapítja, hogy az élvonalba kerüléshez a következőkre van szükség: (1) tehetséges és felkészült professzorok és hallgatók koncentrációja; (2) bőséges források a kiemelkedő kutatási teljesítmény és a gazdag tanulási környezet biztosításához; (3) stratégiai jövőképpel rendelkező, az innovációt és rugalmasságot támogató, döntésképes, a bürokrácia csapdáit elkerülő kormányzás (Salmi, 2009, 6-7.). Másképpen fogalmazva: azok juthatnak be az élbolyba, akiknél a tehetség és a tudás eléri a kritikus tömeget, forrásokban nincs hiány, a vezetők pedig okosan és szabadon irányítják a szervezetet. Ezekre a feltételekre kétségtelenül szükség van; a magunk részéről a megvalósítással kapcsolatban fo- 
galmazunk meg néhány javaslatot, illetve müködési elvet, majd röviden kitérünk a finanszírozás kérdésére is.

Hogyan valósítható meg egy több intézményt érintő egyetemi reform? A nemzetközi tapasztalatok szerint a „frontális támadás” túlságosan kockázatos és nehéz művelet. Ezért ajánlatosabb a tervezett reformokat előbb szükebb körben, például egy kiválasztott egyetemi karon, tanszékcsoportban fokozatosan bevezetni, tanulni a tapasztalatokból, majd a sikeresen kiépített hídfóállásokból tovább terjeszkedni. A hazai felsőoktatási rendszerben ma is léteznek olyan egységek, amelyek egy vagy több nemzetközileg elismert kutatócsoporttal vagy tanszékkel rendelkeznek, és a hazai átlagnál szorosabban zárkóznak fel a nemzetközi élmezőnyhöz. A kísérletező megközelítés irányt mutat, csökkenti az elkerülhetetlen befektetések kockázatát, segíti a tanulást, meggyőzi a kételkedőket.

A kísérlethez biztosítani kell a szükséges anyagi feltételeket, költségvetését el kell különíteni az anyaegyetem átfogó költségvetésétől. A költségvetés nagyságát úgy célszerü meghatározni, hogy a kiválasztott részleg rákényszerüljön saját bevételek szerzésére is (tandijak, kutatási pályázatok), hiszen a „tudáspiaci” siker, a pénzügyi több lábon állás a nemzetközi versenyképesség elengedhetetlen feltétele. Állami támogatásra természetesen szükség van, mivel az egyetemek jelenlegi forrásai (ide értve a meglévő állami támogatást, a tandíjakat és a piaci bevételeket) nem elegendőek. Mindazonáltal gondosan körül kell határolni az állami bábáskodás mértékét és módját, hiszen nem az a cél, hogy az állam mesterséges környezetet teremtsen a kiválasztott intézmény körül, és a valódi siker helyett annak látszatát hozzuk létre. Az eredményeket az oktatási-kutatási piacnak kell visszaigazolnia, az állami és piaci impulzusokat tehát óvatosan kell adagolni.

Tíz pontban foglaljuk össze a kísérlethez kiválasztott egység müködési szabályaira vonatkozó javaslatainkat. Mivel a pontok feltételezik és kölcsönösen kiegészítik egymást, nem lehet tetszés szerint válogatni közöttük.

1. A kísérlethez kiválasztott egyetemi szervezeti egységben a tanároknak nemzetközileg versenyképes, a fejlett európai államokéhoz igazodó bért kell adni.

2. A kiválasztott egységben világszínvonalú infrastruktúrát kell kiépíteni az oktatói és kutatói munkához, igazodva az adott szakterület sajátosságaihoz.

3. A kísérletet a kiválasztott részleg meglévő munkatársaival kell elindítani, a továbbiakban azonban tanárokat a nemzetközi akadémiai munkaerőpiacon kell toborozni, szem elött tartva a nemzetközi versenyképességet. Ebből az is következik, hogy néhány év után az új munkatársak (köztük hazatérö magyarok vagy külföldiek) akár többségbe is kerülhetnek. Külföldiek alkalmazásához angol nyelvü képzési programokra, valamint angol nyelvet használó munkakörnyezetre (tananyagok, adminisztráció, értekezletek, belső és külső kommunikáció stb.) van szükség. A belső utánpótlást észszerü mértékre kell korlátozni, egészséges arányt kell kialakítani a hazai és a kül- 
földi munkatársak között, elkerülve a belterjességet, biztosítva a gondolatok szabad be- és kiáramlását, a rendszeres és módszeres akadémiai megújulást és vérfrissítést. Ha az utánpótlás mégis a saját doktori iskolából történik, akkor olyan jelöltet kell választani, aki a végzés után már értékes külföldi oktatói és kutatói tapasztalatokat szerzett. Következetesen és hitelesen kell közvetíteni a tanári kar felé azt az elvárást, hogy egyetemi karrierjük, az akadémiai ranglétrán való előmenetelük alapja a nemzetközi színvonalú kutatási és oktatási teljesítmény.

4. Érvényesíteni kell azt az általános elvet, hogy a munkaidő egyik felét oktatásra, a másikat kutatásra lehet és kell fordítani, tehát csökkenteni kell a jelenlegi oktatási terheket (óraszámokat). Akik kiemelkedő kutatási eredményt érnek el, kapjanak további könnyítést! A tehetséges és felkészült fiatal kutatókat nem szabad oktatással túlterhelni, elegendő időt kell biztosítani számukra kutatói pályájuk elindításához. Arra is szükség van, hogy versenyképes nagyságú kutatási támogatás álljon rendelkezésre kisebb méretü, magvető (seed) jellegü, referenciákat teremtő, az egyetem számára fontos kutatási projektekhez.

5. A nemzetközi téren is sikeres kutatás fontos feltétele, hogy a tanárok meghatározott időközönként és/vagy időigényes adminisztratív feladatok ellátása után több hónapos szabadságra mehessenek, és ebben az időszakban kutatási és publikálási feladataikra koncentrálhassanak. A sabbatical-rendszernek tervszerünek, szervezettnek és ellenőrzöttnek kell lennie! Szabadságuk ideje alatt a tanárok élvonalbeli intézményeknél foglalkozzanak kutatási projektjükkel, ezzel is segítve a tudományos együttmüködést, a gondolatok szabad áramlását.

6. A tudományos teljesítmény értékelésének a tekintélyes, referált nemzetközi szakmai folyóiratokban történő publikálás és a kutatási pályázatok sikeressége legyen az alapja!

7. Az oktatási teljesítményt nemzetközi normák és gyakorlatok alapján kell értékelni.

8. A kutatási pályázatokhoz adminisztratív és pénzügyi támogatást kell nyújtani. Pályázati irodát kell felállítani és működtetni, hogy a pályázással járó adminisztratív és szervezési feladatok minél kevesebb időt raboljanak el a kutatóktól.

9. El kell kerülni az adminisztratív irányítói hatalom koncentrálódását és megcsontosodását. A magasabb beosztású vezetők megbízatási idejét korlátozni kell, és a tanszékvezetőknél is ajánlott a rotációs rendszer bevezetése a teljesítmény rendszeres értékelése mellett.

10. Minden részleg teljesítményét rendszeresen értékelni kell tekintélyes külföldi egyetemi oktatók közremüködésével. Az egyetemen belül a jelentések legyenek mindenki számára hozzáférhetőek! 
A fenti általános működési szabályokat természetesen a kiválasztott részleg szakmai sajátosságaihoz kell igazítani. A kísérletezés alapvető célja a tanulás, valamint az eredményesnek bizonyuló megoldások fokozatos elterjesztése. Úgy gondoljuk, hogy komolyabb eredmények négy-öt év után várhatók, a kiterjesztés pedig további éveket vesz igénybe.

1. táblázat. Európai országok felsőoktatási adatai

\begin{tabular}{|c|c|c|c|c|c|c|}
\hline Ország & 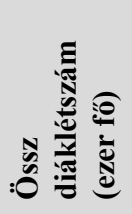 & 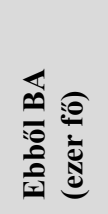 & 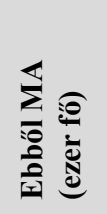 & 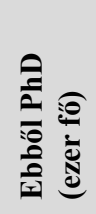 & 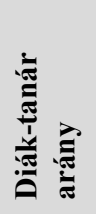 & 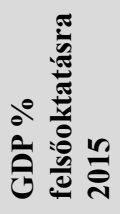 \\
\hline Ausztria & 431,1 & 192,5 & 137,8 & 23,5 & 14,4 & 1,8 \\
\hline Belgium & 508,3 & 369,3 & 98,0 & 16,7 & 21,2 & 1,5 \\
\hline Bulgária & 266,7 & 178,4 & 81,6 & 6,8 & 12,4 & 0,7 \\
\hline Cseh Köztársaság & 371,9 & 221,2 & 125,6 & 24,2 & 18,9 & 0,8 \\
\hline Dánia & 314,8 & 195,7 & 74,6 & 9,8 & 11,2 & 2,4 \\
\hline Egyesült Királyság & 2387,3 & 1563,5 & 415,7 & 113,0 & 15,8 & 1,4 \\
\hline Észtország & 51,1 & 33,1 & 15,1 & 2,8 & 13,9 & 1,4 \\
\hline Finnország & 297,2 & 215,2 & 62,4 & 19,5 & 15,3 & 1,9 \\
\hline Franciaország & 2480,2 & 1025,4 & 890,4 & 67,7 & 17,5 & 1,3 \\
\hline Hollandia & 836,9 & 635,9 & 165,6 & 15,1 & 14,8 & 1,6 \\
\hline Lengyelország & 1600,2 & 1058,9 & 497,7 & 43,2 & 14,6 & 1,2 \\
\hline Lettország & 84,3 & 49,4 & 17,4 & 2,3 & 18,4 & 1,2 \\
\hline Litvánia & 133,8 & 102,4 & 28,6 & 2,7 & 16,3 & 1,2 \\
\hline Magyarország & 295,3 & 200,0 & 76,1 & 7,3 & 13,7 & 0,7 \\
\hline Németország & 3043,1 & 1832,5 & 1013,3 & 197,0 & 12,1 & 1,3 \\
\hline Olaszország & 1816,0 & 1075,5 & 699,2 & 32,9 & 20,2 & 0,8 \\
\hline Portugália & 343,1 & 202,2 & 115,5 & 19,1 & 14,4 & 0,9 \\
\hline Románia & 535,2 & 352,7 & 165,2 & 17,3 & 18,7 & 0,7 \\
\hline Spanyolország & 1968,7 & 1207,3 & 337,2 & 55,6 & 12,2 & 1,0 \\
\hline Svédország & 426,2 & 243,0 & 138,0 & 20,7 & 10,4 & 1,9 \\
\hline Szlovákia & 167,3 & 92,6 & 63,7 & 8,2 & 15,1 & 1,4 \\
\hline Szlovénia & 80,8 & 45,3 & 22,0 & 2,3 & 15,3 & 1,0 \\
\hline
\end{tabular}

Eurostat (URL4) 
A következő kérdés az, hogy a fokozatos kiterjesztéssel meddig lehet, illetve célszerü elmenni, vagyis milyen intézményi arányok alakulhatnak ki a hazai felsőoktatásban, és mindez mekkora anyagi terhet jelent az ország számára.

Az 1. táblázat az európai országok 2015. és 2016. évi felsőoktatási adatait mutatja. Ebben az évben Magyarországon mintegy 295 ezer diák tanult a felsőoktatási intézményekben, nagyjából annyian, mint Finnországban. Tegyük hozzá: hazánkban az ezredforduló óta az aktív népesség körében jelentősen növekedett a felsőfokú végzettséggel rendelkezők aránya. E tekintetben nagyjából a csehekkel, a szlovákokkal és a horvátokkal állunk azonos szinten, de elmaradunk az EU28 átlagától, és számottevő a lemaradásunk az észtek, a litvánok vagy a szlovének mögött. A táblázatból kiolvashatjuk, hogy az adott évben hányan vettek részt alap-, mester-, illetve doktori képzésben. A diák-tanár arány tekintetében a középmezőnyben helyezkedünk el.

Az utolsó oszlop azt mutatja, hogy az országok GDP-jük hány százalékát fordították a felsőoktatás finanszírozására. Látható, hogy e tekintetben jelentős a lemaradásunk, a felsorolt országok közül Bulgáriával és Romániával vagyunk azonos szinten. A magyar GDP 2015-ben 111 milliárd euró volt, ennek a 0,7\%-a 0,8 milliárd euró, tehát körülbelül ennyit költöttünk felsőoktatásra.

Végezzünk most el egy nagyvonalú gondolatkísérletet! Tételezzük fel, hogy miközben a tanulók összlétszáma változatlan, sikerül elérni, hogy az alapképzésben tanulók $20 \%$-a, a mesterképzés diákjainak $50 \%$-a és valamennyi doktori hallgató a globális rangsorok szempontrendszere szerint versenyképes tudományegyetemekre jár. Ez összesen 85 ezer diákot érint. Ha a finanszírozást versenyképes szintre emeljük, ami annyit jelent, hogy ezer diákra (a nemzetközi tapasztalatok alapján) 13-15 millió eurót számolunk, akkor 85 ezer diák esetében összesen 1250 millió eurós kiadást kapunk. Számításaink szerint ahhoz, hogy ennyi diákot globálisan versenyképes tudományegyetemi képzésben lehessen részesíteni, a GDP-arányos felsőoktatási kiadást $0,7 \%$-ról fokozatosan 1,7\%-ra, vagyis nagyjából Ausztria vagy Finnország szintjére kell emelni, mondjuk tíz-tizenöt év alatt. Ez nem lehetetlen, és feltétlenül megéri a befektetést, ha valóban tudásalapú társadalmat akarunk építeni!

A kísérlethez és a modell kiterjesztéséhez természetesen a fentieknél részletesebb és pontosabb pénzügyi számításokat kell készíteni. Ennek során a kezdeti beruházásokon túl feltétlenül számolni kell a fenntartáshoz szükséges folyó kiadásokkal is.

Végezetül röviden szólnunk kell a kockázatokról. Várható, hogy az egyes intézmények és részlegek fenti módon történő kiemelése, a megszokottól eltérő müködési szabályok érvényesítése konfliktusokat és ellenállást vált ki, ami, ha nem kezelik megfelelően, idővel felpuhíthatja a rendszert. A másik veszély az átpolitizálódás, vagyis a mindenféle politikai, hatalmi érdekek megjelenése és érvényesülése a döntésekben. Magyarországon sajnos erre is jó esély van. 
Valódi és tartós eredményeket csak a megfogalmazott müködési elvek következetes és hiteles érvényesítése hozhat. A hitelesség jelentőségét nem lehet eléggé hangsúlyozni: támogató és szilárd jogi keretekre, reális és fenntartható költségvetésre van szükség; a hitelességet igazolja, ha sikerül neves külföldi munkatársakat megszerezni, külföldön dolgozó, nemzetközi hírü magyarokat hazacsábítani. Hiteles vezetők kiválasztása üzenet az érintettek felé: a programot komolyan kell venni, a szakmaiság biztosított, a célok szilárdak, a vezetők felül tudnak emelkedni a politikai csatározásokon. A vezetőknek példát kell mutatniuk, saját példájukon is bizonyítaniuk kell a megfogalmazott müködési elvek fontosságát.

\section{IRODALOM}

Berács J. - Derényi A. - Kováts G. et al. (2015): Magyar felsőoktatás 2014. Stratégiai helyzetértékelés. Köz-gazdaság: tudományos füzetek, 1. rész: 10, 1, 205-232; 2. rész: 10, 2, 41-66. http:// unipub.lib.uni-corvinus.hu/1849/1/MF2014_strat.pdf

Berlinger E. - Megyeri K. (2015): Mélyszegénységből a felsőoktatásba. Közgazdasági Szemle, LXII, június, 674-699. http://real.mtak.hu/24514/1/07_BerlingerMegyeri_u.pdf

Fábri Gy. (2016): Az egyetem értéke. Budapest: ELTE Eötvös Kiadó, http://www.eltereader.hu/ media/2017/04/Az_Egyetem_Erteke_1-4_10_11.pdf

Hazelkorn, E. (2015): Rankings and the Reshaping of Higher Education. Basingstoke: Palgrave Macmillan

Mihályi P. (2018): A magyar felsőoktatás jobbításának négy akadálya. Valóság, 61, 2, 94-98. https://epa.oszk.hu/02900/02924/00062/pdf/EPA02924_valosag_2018_02_094-098.pdf

Polónyi I. - Tímár J. (2001): Tudásgyár vagy papírgyár. Budapest: Új Mandátum Könyvkiadó

Salmi, J. (2009): The Challenge of Establishing World-Class Universities. Washington: The World Bank, https://siteresources.worldbank.org/EDUCATION/Resources/278200-1099079877269/ 547664-1099079956815/547670-1237305262556/WCU.pdf

Stack, M. (2016): Global University Rankings and the Mediatization of Higher Education. Basingstoke: Palgrave Macmillan

URL1: http://www.shanghairanking.com/ARWU2018.html

URL2: https://www.timeshighereducation.com/

URL3: https://www.qs.com/

URL4: https://ec.europa.eu/eurostat/statistics-explained/index.php/Tertiary_education_statistics\#Participation 